Provided for non-commercial research and education use. Not for reproduction, distribution or commercial use.

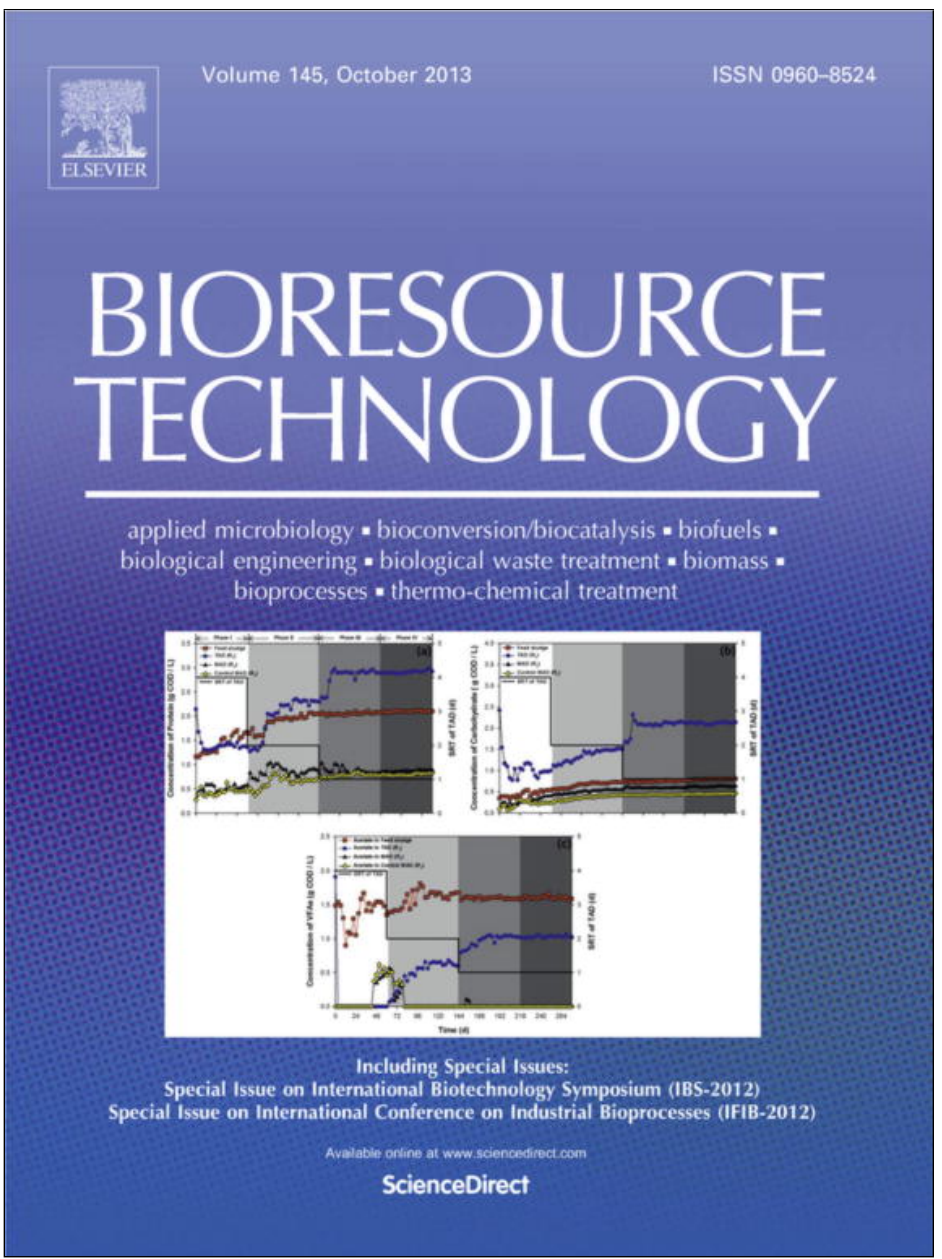

This article appeared in a journal published by Elsevier. The attached copy is furnished to the author for internal non-commercial research and education use, including for instruction at the authors institution and sharing with colleagues.

Other uses, including reproduction and distribution, or selling or licensing copies, or posting to personal, institutional or third party websites are prohibited.

In most cases authors are permitted to post their version of the article (e.g. in Word or Tex form) to their personal website or institutional repository. Authors requiring further information regarding Elsevier's archiving and manuscript policies are encouraged to visit:

http://www.elsevier.com/authorsrights 


\title{
Bio-oil from cassava peel: A potential renewable energy source
}

\author{
Ong Lu Ki ${ }^{\text {a,1 }}$, Alfin Kurniawan ${ }^{\text {a,1 }}$, Chun Xiang Lin ${ }^{\text {b }}$, Yi-Hsu Ju ${ }^{c}$, Suryadi Ismadji ${ }^{\text {a,* }}$ \\ ${ }^{a}$ Department of Chemical Engineering, Widya Mandala Surabaya Catholic University, Kalijudan 37, Surabaya 60114, Indonesia \\ ${ }^{\mathrm{b}}$ School of Chemical Engineering, The University of Queensland, St. Lucia, Brisbane, QLD 4072, Australia \\ ${ }^{\mathrm{c}}$ Department of Chemical Engineering, National Taiwan University of Science and Technology, 43, Sec. 4, Keelung Road, Taipei 106-07, Taiwan
}

\section{H I G H L I G H T S}

- Cassava peel was utilised as a potential biomass feedstock to produce bio-oil.

- A relatively high yield of bio-oil was obtained through slow pyrolysis at $525^{\circ} \mathrm{C}$.

- The distribution of organic moieties in bio-oil is not dependent on temperature.

- The physicochemical properties of bio-oil satisfied ASTM D7544 requirements.

- The yield of pyrolysis products was predicted by kinetic-based mechanistic model.

\section{A R T I C L E I N F O}

\section{Article history:}

Available online 9 February 2013

\section{Keywords:}

Cassava peel

Bio-oil

Fixed-bed reactor

Slow pyrolysis

Mechanistic model

\begin{abstract}
A B S T R A C T
In this work, liquid biofuel (bio-oil) was produced by pyrolizing cassava peel. The experiments were conducted isothermally in a fixed-bed tubular reactor at temperatures ranging from 400 to $600{ }^{\circ} \mathrm{C}$ with a heating rate of $20^{\circ} \mathrm{C} / \mathrm{min}$. The chemical compositions of bio-oil were analyzed by a gas chromatography mass spectrometry (GC-MS) technique. For the optimization of liquid product, temperature was plotted to be the most decisive factor. The maximum yield of bio-oil ca. $51.2 \%$ was obtained at $525{ }^{\circ} \mathrm{C}$ and the biofuel has a gross calorific value of $27.43 \mathrm{MJ} / \mathrm{kg}$. The kinetic-based mechanistic model fitted well with experimental yield of pyrolysis products with the mean squared error (MSE) of $13.37\left(R^{2}=0.96\right)$ for solid (char), $16.24\left(R^{2}=0.95\right)$ for liquid (bio-oil), and $0.49\left(R^{2}=0.99\right)$ for gas.
\end{abstract}

(C) 2013 Elsevier Ltd. All rights reserved.

\section{Introduction}

Current technologies available to convert biomass into fuels can be classified into three categories based on their methodologies namely biochemical, thermal, and thermochemical conversion. Thermochemical conversion of biomass includes a number of processes such as liquefaction, gasification, and pyrolysis (Park et al., 2012). Among these, pyrolysis is the main spotlight of thermochemical conversion of biomass that produces solid and liquid fuels, both are easy to handle and transport (Van de Velden et al., 2010). The liquid fuel (bio-oil) contains various added-value chemicals in economical recoverable concentrations and can be upgraded into refined fuels for transportation purpose (Volli and Singh, 2012).

Cassava (Manihot esculenta) is extensively cultivated in Indonesia as one of major staple food resources as well as a multipurpose agro-industrial crop. Cassava starch is a high value commodity for

\footnotetext{
* Corresponding author. Tel.: +62 313891264; fax: +62 313891267.

E-mail address: suryadiismadji@yahoo.com (S. Ismadji).

1 These authors contributed equally to this work.
}

various industries such as brewing, paper, adhesives, plastics, and chemicals. The peel waste that generated from the cassava starch manufacturing industries is of great concern to the environment. Since cassava peel contains cyanogenic glucosides mainly linamarin and lotaustralin, the disposal and improper handling of this waste often create an environmental problem due to the release of hydrogen cyanide $(\mathrm{HCN})$ from cyanogenesis activity of endogenous linamarase enzyme (Cooke, 1978). Several research groups have employed cassava peel as a potential feedstock to prepare electrode materials for supercapacitors (Ismanto et al., 2010) and cheap biosorbent for sequestering heavy metal ions (Kosasih et al., 2010; Kurniawan et al., 2011).

Several studies on the utilisation of cassava plant residues for bio-oil production have recently been reported in the literatures (Pattiya, 2011; Pattiya et al., 2012). In their studies, Pattiya and his co-workers use rhizome and stalk of cassava plant as biomass feedstocks to obtain bio-oil by fast pyrolysis process in two types of reactors namely fluidized-bed reactor (Pattiya, 2011) and freefall reactor (Pattiya et al., 2012). Another work has been conducted by Weerachanchai et al. (2011) dealing with slow paralysis of cassava pulp residue and palm kernel cake and its product 
characterization includes solid, liquid, and gas. In this work, cassava peel is used as a raw material to produce bio-oil through slow pyrolysis process in a fixed-bed reactor. The effect of pyrolysis temperatures on the physicochemical properties of bio-oil was studied. Furthermore, a kinetic-based mechanistic model for predicting the yield of char, bio-oil, and gas was also given in this paper.

\section{Methods}

\subsection{Preparation and analysis of biomass feedstock}

Cassava peel was collected from a cassava starch factory located near Surabaya, Indonesia. Prior to use, the biomass was repeatedly washed using tap water to remove surface dirt and dried in an oven for $24 \mathrm{~h}$ at $110{ }^{\circ} \mathrm{C}$ to substantially reduce its moisture content from about $10 \%$ to less than $2 \%$. Subsequently, the dried peel was crushed by an IKA-Labortechnick grinder and sieved pass through $80 / 100$ mesh screen to obtain powder with particle sizes of 150 $180 \mu \mathrm{m}$.

The chemical composition of the biomass was analyzed by a Perkin-Elmer $2400 \mathrm{CHNS} / 0$ elemental-analyzer and the following results were obtained: $\mathrm{C}$ of $53.7 \%, \mathrm{H}$ of $7.1 \%, \mathrm{~N}$ of $1.2 \%, \mathrm{~S}$ of $0.1 \%$, and $\mathrm{O}$ of $37.9 \%$ (measured by difference). The proximate analysis of cassava peel was conducted according to the established procedures of ASTM D4442-07 for moisture content, ASTM E1755-01 for ash content, and ASTM D3175-11 for volatile matter content. The fixed carbon content was calculated by subtracting the initial weight of the sample (100\%) by total percentage of moisture, ash, and volatile matter. The proximate analysis results of cassava peel were given as follows: fixed carbon (FC) of $21.4 \%$, volatile matter (VM) of $74.5 \%$, ash $(\mathrm{A})$ of $2.3 \%$, and moisture $(\mathrm{M})$ of $1.8 \%$. The heating value of the biomass was $17.9 \mathrm{MJ} / \mathrm{kg}$ (reported as higher heating value or gross caloric value), as measured by an oxygen bomb calorimeter (Model 1341, Parr Instrument Co.) by following ASTM D5865-12 test method.

\subsection{Thermogravimetric analysis (TGA)}

Thermal stability of the biomass material was studied by thermogravimetric analysis. The analysis was performed in a TGA/ DSC 1 STAR $^{\circledR}$ System (Mettler-Toledo) with a heating and cooling rate of $10^{\circ} \mathrm{C} / \mathrm{min}$ and nitrogen (99.99\%) was used as the carrier gas at a constant flow rate of $70 \mathrm{ml} / \mathrm{min}$. Approximately, $10 \mathrm{mg}$ of sample was heated in nitrogen atmosphere from room temperature to $800^{\circ} \mathrm{C}$ at a given heating rate.

\subsection{Fixed-bed pyrolysis experiments}

Slow pyrolysis experiments of cassava peel were performed in a fixed-bed reactor system. The reactor was made from 316-grade stainless steel with a maximum working temperature of $1000^{\circ} \mathrm{C}$ at atmospheric pressure. Brief procedure of the experiments is described as follows: One hundred grams of cassava peel were introduced into the reactor. Subsequently, nitrogen at a flow rate of $3 \mathrm{~L} /$ min was introduced to the reactor for removing air and maintaining inert condition. The reactor was heated at $20^{\circ} \mathrm{C} / \mathrm{min}$ from room temperature to desired temperatures $\left(400-600^{\circ} \mathrm{C}\right.$ ) and held isothermally for a certain time. After pyrolysis time reached, the reactor was cooled rapidly to room temperature in order to avoid any advancing reactions. The gas and vapor products that generated from the thermal cracking of biomass were passed to a condenser in which the condensable volatiles were converted to liquid form and collected in a measuring cylinder as bio-oil. At the exit of condensing system, a cotton wool filter was installed to capture low partial pressure hydrocarbons. The non-condensable gases together with the carrier gas were passed to a flowmeter where the volume of exit gases was recorded. The yield of char and bio-oil was determined by weighing the mass of both products until constant using an analytical balance (Precisa 3000D).

\subsection{Analysis of physical and chemical properties of bio-oil}

The chemical composition of bio-oil was analyzed by a Shimadzu GC/MS QP2010 equipped with a DB-5 MS capillary column $(30 \mathrm{~m} \times 0.25 \mathrm{~mm} \times 0.25 \mu \mathrm{m})$ as the stationary phase. The injector temperature was set at $250^{\circ} \mathrm{C}$ while the oven temperature was initially programmed at $60^{\circ} \mathrm{C}$ for $1 \mathrm{~min}$ then ramped at $10^{\circ} \mathrm{C} /$ $\mathrm{min}$ to $300^{\circ} \mathrm{C}$ and held for $5 \mathrm{~min}$. Helium was employed as the carrier gas at a flow rate of $1.5 \mathrm{ml} / \mathrm{min}$. For the mass selective detector (MSD), the temperature of the ion source was $230^{\circ} \mathrm{C}$. The sample was injected into the column in split mode with a ratio of 1:30. Identification of the chemical constituents in bio-oil was conducted by comparing the mass spectra of the sample with the National Institute of Standards and Technology (NIST) database. The gross heat of combustion of bio-oil was determined by an oxygen bomb calorimeter based on ASTM D240. Other physical and chemical properties were analyzed by following ASTM test methods: density (ASTM 4052), pH (ASTM E70), kinematic viscosity (ASTM D445), pyrolysis solids content (ASTM D7579), water content (ASTM E203), sulfur content (ASTM D4294), ash content (ASTM D482), pour point (ASTM D97), and flash point (ASTM D93).

\section{Results and discussion}

\subsection{Thermal characteristics of the biomass}

Thermogravimetric analysis was conducted in order to obtain valuable information regarding the thermal stability of the materials, associated with the mass change as a function of temperature and/or time (figure not shown here). At initial heating zone $\left(T<200^{\circ} \mathrm{C}\right)$, the weight reduction in biomass primarily attributed to the moisture removal (or physically-bound water). The active pyrolysis zone was observed in temperature range of $200-500^{\circ} \mathrm{C}$ where the weight of biomass considerably diminished due to the decomposition of natural polymer materials such as hemicellulose, cellulose, and lignin. Thermal degradation of hemicellulose and cellulose took place at temperatures between 200 and $350{ }^{\circ} \mathrm{C}$ while lignin was decomposed at higher temperatures, typically between 280 and $500{ }^{\circ} \mathrm{C}$ (Park et al., 2012).

\subsection{Effect of pyrolysis temperature on the distribution of products}

The yield percentage of solid, liquid, and gas obtained from slow pyrolysis of cassava peel at various temperatures are shown in Table 1 . It can be seen that the yield of char diminished from $37.5 \%$ to $20.8 \%$ while the yield of gases continuously rise from $23.8 \%$ to $37.6 \%$ with increasing temperatures from 400 to $600{ }^{\circ} \mathrm{C}$. This might be ascribed to the enhanced extent of primary cracking reaction of the biomass at higher temperatures. At temperatures above $525^{\circ} \mathrm{C}$, the combination of primary and secondary crackings increases the yield of gases. In other hand, the experimental trend of liquid yield with temperature was slightly different to that of solid and gas in which the yield of bio-oil increases and reaches its maximum at $525{ }^{\circ} \mathrm{C}$ then it gradually decreased from $51.2 \%$ to $41.6 \%$ at higher temperature, likely due to the secondary thermal cracking. 
Table 1

Yield and products distribution from slow pyrolysis process of cassava peel.

\begin{tabular}{|c|c|c|c|c|c|c|}
\hline \multirow[t]{2}{*}{$T\left({ }^{\circ} \mathrm{C}\right)$} & \multicolumn{3}{|l|}{ Experimental } & \multicolumn{3}{|l|}{ Simulation } \\
\hline & Solid (wt.\%) & Liquid (wt.\%) & Gas (wt.\%) & Solid (wt.\%) & Liquid (wt.\%) & Gas (wt.\%) \\
\hline 400 & 37.5 & 38.7 & 23.8 & 41.3 & 34.6 & 24.1 \\
\hline 425 & 34.3 & 41.8 & 23.9 & 37.9 & 38.0 & 24.2 \\
\hline 450 & 29.6 & 46.9 & 23.5 & 32.7 & 43.0 & 24.4 \\
\hline 475 & 26.8 & 48.2 & 25.0 & 29.5 & 46.0 & 24.5 \\
\hline 500 & 25.1 & 50.3 & 24.6 & 27.6 & 47.8 & 24.6 \\
\hline 525 & 24.3 & 51.2 & 24.5 & 26.7 & 47.5 & 25.7 \\
\hline 550 & 22.9 & 48.7 & 28.4 & 25.4 & 47.4 & 27.4 \\
\hline 575 & 21.4 & 45.4 & 33.2 & 23.2 & 43.6 & 32.8 \\
\hline 600 & 20.8 & 41.6 & 37.6 & 22.9 & 43.4 & 33.7 \\
\hline \multirow{2}{*}{\multicolumn{4}{|c|}{$\begin{array}{l}\text { Mean squared error (MSE) } \\
\text { Coefficient of determination }\left(R^{2}\right)\end{array}$}} & 13.37 & 16.24 & 0.49 \\
\hline & & & & 0.96 & 0.95 & 0.99 \\
\hline
\end{tabular}

3.3. Kinetic-based mechanistic modeling of experimental yield of pyrolysis products

The kinetic-based mechanistic model was purposely developed in this study for predicting the yield of pyrolysis products at any temperature and time. The reaction scheme of slow pyrolysis process in this study was similar to that of Van de Velden et al. (2008). Based on this reaction scheme, the kinetic equations representing the decomposition rate of biomass and the formation rate of char, liquid, and gas as a function of time can be expressed as follows:

$\frac{d X_{\mathrm{B}}}{d t}=-\left(k_{1}+k_{2}+k_{3}\right) \cdot X_{\mathrm{B}}=-k \cdot X_{\mathrm{B}}$

$\frac{d X_{\mathrm{G} 1}}{\mathrm{~d} t}=k_{1} \cdot X_{\mathrm{B}}$

$\frac{d X_{01}}{\mathrm{~d} t}=k_{2} \cdot X_{\mathrm{B}}$

$\frac{d X_{\mathrm{C}}}{\mathrm{d} t}=k_{3} \cdot X_{\mathrm{B}}$

$\frac{d X_{02}}{\mathrm{~d} t}=\frac{d X_{\mathrm{G} 2}}{d t}=k_{4} \cdot X_{01}$

where $X$ is the mass fraction and the subscripted notations B, C, G1, $\mathrm{O} 1, \mathrm{G} 2$, and $\mathrm{O} 2$ refer to biomass, char, primary gases, primary liquid, secondary gases, and secondary liquid, respectively. The time domain $(t)$ was designated as a time when the heating was started until the process completed. Concerning the real reaction system in this work, the residence time of biomass in the reactor where primary cracking took place was considered as the whole time domain. At initial condition $(t=0), X_{\mathrm{C}}=X_{\mathrm{G} 1}=X_{\mathrm{O} 1}=X_{\mathrm{G} 2}=X_{\mathrm{O} 2}=0$ and $X_{\mathrm{B}}=1$. Integrating Eqs. (1) $-(5)$ from $t=0$ to $t=$ t gives:

$X_{\mathrm{B}}=\exp (-k t)$

$X_{\mathrm{G} 1}=k_{1} \cdot k^{-1} \exp (-k t)$

$X_{01}=k_{2} \cdot k^{-1} \exp (-k t)$

$X_{\mathrm{C}}=k_{3} \cdot k^{-1} \exp (-k t)$

The yield of secondary liquid ( $\mathrm{O} 2)$ and secondary gases (G2) on each time interval of the hydraulic time (i.e. the volume of the reactor divided by the $\mathrm{N}_{2}$ flow rate) was simultaneously determined along with the yield of primary oil by applying Euler numerical method on Eq. (5). The first-order rate constants in Eqs. (6)-(9) were determined using the same approach described by Van de Velden et al. (2008). In this regard, the dynamic TGA experiments with a heating rate of ca. $100 \mathrm{~K} / \mathrm{min}$ was used to obtain an accurate value of the overall rate constant of primary cracking reaction $(k$, $\mathrm{s}^{-1}$ ). The average values of rate constants for the formation of primary gases (G1) and secondary products ( $\mathrm{G} 2$ and $\mathrm{O} 2$ ) were taken from the literature (Di Blasi, 2005). Once the values of $k_{1}$ (the formation rate constant of primary gases, $\mathrm{s}^{-1}$ ) and $k_{4}$ (the rate constant of secondary cracking, $\mathrm{s}^{-1}$ ) had been known, the values of remaining rate constants, $k_{2}$ (the formation rate constant of primary oil, $\mathrm{s}^{-1}$ ) and $k_{3}$ (the formation rate constant of char, $\left.\mathrm{s}^{-1}\right)$ ), could be determined (Van de Velden et al., 2008). The calculated values of all rate constants were given as follows:

$k=28057.18 \exp \left(-81094.76 / R T_{s}\right)$

$k_{1}=14300 \exp \left(-106500 / R T_{s}\right)$

$k_{2}=21332.77 \exp \left(-81053.19 / R T_{s}\right)$

$k_{3}=6431.74 \exp \left(-81094.76 / R T_{s}\right)$

$k_{4}=7900 \exp \left(-81000 / R T_{\text {sys }}\right)$

In this study, the effect of thermal gradient was taken into account because slow heating rates provide small amounts of heat to the system that gradually increases the temperature inside the biomass particle, unlike the case of fast pyrolysis process with a very high heating rate that able to raise the interior temperature of the particle instantaneously. The temperature distribution along the radius of the biomass particle was described by the Fourier's law of heat conduction that has mathematical form:

$\frac{\partial T}{\partial t}=\frac{\kappa}{\rho_{\text {true }} \cdot C_{\mathrm{p}}}\left[\frac{\partial^{2} T}{\partial r^{2}}+\frac{2}{r} \frac{\partial T}{\partial r}\right]=D\left[\frac{\partial^{2} T}{\partial r^{2}}+\frac{2}{r} \frac{\partial T}{\partial r}\right]$

with the following boundary conditions:

$-\left.\kappa \frac{\partial T}{\partial r}\right|_{r=R_{\mathrm{p}}}=h \cdot\left(T_{s}-T_{\text {sys }}\right)$

$\left.\frac{\partial T}{\partial r}\right|_{r=0}=0$

The surface temperature, $T_{s}(K)$, could be determined by solving Eq. (15) numerically with Crank-Nicolson implicit scheme. In solving Eq. (14), the temperature change in the system during heating period and the particle shrinkage were included. The initial temperature of the particles was assumed to be uniform at room temperature $\left(30^{\circ} \mathrm{C}\right)$ in any radius position. For simplification, several assumptions were applied in developing the model:

(i) the shape of the biomass particle is spherical.

(ii) the mechanism of heat transfer inside the biomass particle is only conduction.

(iii) the temperature gradient inside the biomass particle is a function of the radius position with surface temperatures less equal to the temperature in the system ( $\left.T_{\mathrm{s}} \leqslant T_{\text {sys }}\right)$.

(iv) Some physical properties of the biomass such as density, specific heat capacity, and thermal conductivity are constant.

The set of parameter values used in the calculation is as follows: $h=5.69+0.0098 T_{\text {sys }}$ (Ahuja et al., 1996), $C_{\mathrm{p}}=1449 \mathrm{~J} \mathrm{~kg}^{-1} \mathrm{~K}^{-1}$, $\kappa=0.156 \mathrm{~W} \mathrm{~m}^{-1} \mathrm{~K}^{-1}, \quad \rho_{\text {bulk }}=289 \mathrm{~kg} \mathrm{~m}^{-3}, \quad v=0.226$, and $D=$ 


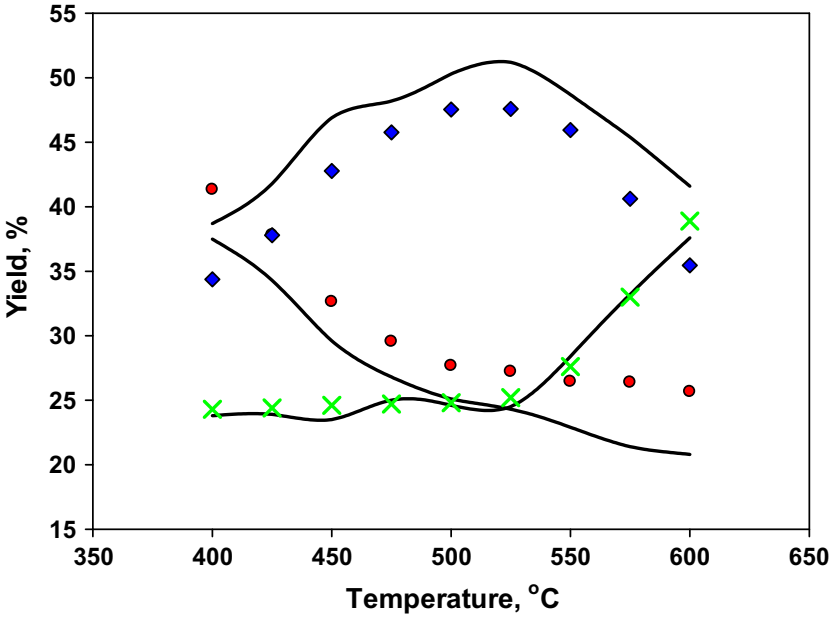

Fig. 1. Comparison results between simulated (solid lines) and experimental yield of pyrolysis products ( $\bullet$ solid, $\mathbf{\square}$ liquid, $\times$ gas).

$2.8834 \times 10^{-7} \mathrm{~m}^{2} . \mathrm{s}^{-1}$. The simulation process was run by using computer programming on the MATLAB platform (Version 7.11, Mathworks Inc.). Thermal conductivity $\left(\kappa, \mathrm{W} \mathrm{m}^{-1} \mathrm{~K}^{-1}\right)$, specific heat capacity $\left(C_{\mathrm{p}}, \mathrm{J} \mathrm{kg}^{-1} \mathrm{~K}^{-1}\right)$, bulk density $\left(\rho_{\text {bulk }}, \mathrm{kg} \mathrm{m}^{-3}\right)$, and void fraction $(v)$ of the biomass particle are experimentally determined based on ASTM E1952, ASTM E1269, and ASTM C29, respectively. True density of the biomass particle was calculated by using the following equation:

$\rho_{\text {true }}=\frac{\rho_{\text {bulk }}}{(1-v)}$

Fig. 1 shows the comparison results between experimental (solid symbols) and simulated (solid lines) yield of solid, liquid, and gas products. A slight error between simulation and experimental results, as reflected by the coefficient of determination $\left(R^{2}\right)$ values, might be ascribed to several following factors such as the non-ideality of the interparticle heat transfer in the bed, the neglected possible carbon-steam and/or carbon-carbon dioxide reactions, and the resistance of carrier gas flow in the pores of the solid particle and void fraction of the bed.

\subsection{Physical and chemical properties of bio-oil}

The organic fraction in bio-oil comprises of acids, esters, aldehydes, ketones, phenols, alcohols, hydrocarbons, and some unidentified compounds. The detail composition of organic compounds in bio-oil is summarized in Table 2. As shown in Table 2, there is no a
Table 3

The physicochemical properties of resulted bio-oil.

\begin{tabular}{lcl}
\hline Properties & Bio-oil & ASTM D7544 \\
\hline Gross calorific value $(\mathrm{MJ} / \mathrm{kg})$ & 27.43 & $15 \mathrm{~min}$ \\
$\mathrm{pH}$ & 4.26 & - \\
Kinematic viscosity $(\mathrm{cSt})$ at $40^{\circ} \mathrm{C}$ & 35.8 & $125 \mathrm{max}$ \\
Density $\left(\mathrm{kg} / \mathrm{dm}^{3}\right)$ at $20^{\circ} \mathrm{C}$ & 1.27 & $1.1-1.3$ \\
Pyrolysis solids content $(\%$ wt.) & 0.12 & $2.5 \mathrm{max}$ \\
Water content $(\%$ wt.) & 23.74 & $30 \mathrm{max}$ \\
Sulfur content $(\%$ wt.) & 0.01 & $0.05 \mathrm{max}$ \\
Ash content $(\%$ wt.) & 0.08 & $0.25 \mathrm{max}$ \\
Flash point $\left({ }^{\circ} \mathrm{C}\right)$ & 78 & $45 \min$ \\
Pour point $\left({ }^{\circ} \mathrm{C}\right)$ & 2 & $-9 \max$ \\
\hline
\end{tabular}

definite trend on the organic distributions in bio-oil as a function of temperature, considering the reaction complexity in the pyrolysis process. Several major components of acid groups in bio-oil were acetic acid, formic acid, propionic acid, and butyric acid. For alcohol groups, methanol is predominant while ethanol was found in a small amount. Phenolic compounds in bio-oil might be generated from the pyrolysis of lignin (Bertero et al., 2012).

The physicochemical properties of resultant bio-oil are given in Table 3. Several properties of bio-oil such as viscosity, density, and flash point are known to be the crucial characteristics for combustion purpose in some equipments such as boiler, furnace, gas turbines, and engines (Volli and Singh, 2012). The flash point of resultant bio-oil was 1.73-fold higher than that of ASTM requirement $\left(78^{\circ} \mathrm{C}\right.$ vs. $\left.45^{\circ} \mathrm{C}\right)$, indicating safer handling and storage of this liquid fuel in high temperature environment. However, the direct use of this fuel for combustion purpose in the conventional diesel engines is not recommended since it contains many kinds of contaminants and has a much higher viscosity of ca. $35.8 \mathrm{cSt}$ than commercial diesel fuels of ca. 1.3-5.5 cSt (ASTM D975). High viscosity led to poor atomization and an incomplete combustion of the fuel as well as the formation of excessive carbon deposits on the injection nozzles and the combustion chamber (Volli and Singh, 2012). Another issue to be tackled was high oxygen content in bio-oil that affected chemical and thermal stability, corrosivity, and immiscibility with hydrocarbon fuels. For upgrading purpose, several methods are available such as catalytic hydrotreatment to lower the oxygen content (Elliott and Neuenschwander, 1996), supercritical water treatment (SCW) to increase the heating value (Duan and Savage, 2011), or esterification-distillation for removing a large quantity of water (Junming et al., 2008).

\section{Conclusions}

The yield of bio-oil from slow pyrolysis of cassava peel were ranged between $38.7 \%$ and $51.2 \%$. The pyrolysis peak temperature

Table 2

Chemical composition of bio-oil at various temperatures.

\begin{tabular}{|c|c|c|c|c|c|c|c|c|c|}
\hline \multirow[t]{2}{*}{ Compounds (wt.\%, dry basis) } & \multicolumn{9}{|c|}{ Temperature $\left({ }^{\circ} \mathrm{C}\right)$} \\
\hline & 400 & 425 & 450 & 475 & 500 & 525 & 550 & 575 & 600 \\
\hline Acids & 20.18 & 17.91 & 17.65 & 22.47 & 18.59 & 19.31 & 24.12 & 23.22 & 18.94 \\
\hline Alcohols & 2.25 & 3.61 & 2.07 & 2.98 & 1.96 & 2.54 & 3.01 & 2.29 & 2.09 \\
\hline Aldehydes and ketones & 14.32 & 14.58 & 8.91 & 12.47 & 17.21 & 7.93 & 13.74 & 14.56 & 12.88 \\
\hline Esters & 8.93 & 7.46 & 9.22 & 8.41 & 7.59 & 7.62 & 8.14 & 8.88 & 9.01 \\
\hline Ethers & 6.82 & 5.43 & 5.79 & 4.14 & 5.64 & 4.87 & 4.21 & 3.98 & 6.02 \\
\hline Phenols & 14.89 & 15.47 & 19.23 & 10.48 & 17.44 & 18.03 & 16.88 & 17.41 & 18.63 \\
\hline Furans & 6.41 & 7.52 & 5.63 & 7.31 & 7.45 & 6.90 & 6.08 & 5.41 & 6.98 \\
\hline Hydrocarbons and its derivatives & 0.89 & 1.22 & 1.54 & 1.21 & 0.83 & 1.32 & 1.98 & 2.11 & 2.61 \\
\hline Nitrogen compounds & 1.21 & 1.47 & 1.32 & 1.89 & 1.10 & 1.18 & 1.48 & 1.51 & 1.73 \\
\hline Oxygenated cyclic compounds & 3.94 & 2.98 & 2.71 & 2.69 & 3.07 & 3.58 & 3.49 & 2.55 & 3.41 \\
\hline Unknowns & 20.16 & 22.35 & 25.93 & 25.95 & 19.12 & 26.72 & 16.87 & 18.08 & 17.70 \\
\hline
\end{tabular}


that gave maximum liquid yield was observed at $525^{\circ} \mathrm{C}$. The biooil was mainly composed of several organic classes such as acids, esters, aldehydes, ketones, phenols, alcohols, hydrocarbons, and other unidentified compounds. All physical and chemical properties of bio-oil satisfied ASTM D7544 standard. The kinetic-based mechanistic model gives good accuracy in representing the experimental yield of pyrolysis products with the mean squared error of 13.37 for solid (char), 16.24 for liquid (bio-oil), and 0.49 for gas.

\section{References}

Ahuja, P., Kumar, S., Singh, P.C., 1996. A model for primary and heterogeneous secondary reactions of wood pyrolysis. Chem. Eng. Technol. 19, 272-282.

Bertero, M., de la Puente, G., Sedran, U., 2012. Fuels from bio-oils: bio-oil production from different residual sources, characterization and thermal conditioning. Fuel 95, 263-271.

Cooke, R.D., 1978. An enzymatic assay for the total cyanide content of cassava (Manihot esculenta Crantz). J. Sci. Food Agric. 29, 345-352.

Di Blasi, C., 2005. Kinetics and modeling of biomass pyrolysis. In: Bridgwater, A.V. (Ed.), Fast Pyrolysis of Biomass: A Handbook Volume 3. CPL Press, Newbury, pp. 121-146.

Duan, P., Savage, P.E., 2011. Upgrading of crude algal bio-oil in supercritical water. Bioresour. Technol. 102, 1899-1906.

Elliott, D.C., Neuenschwander, G.G., 1996. Liquid fuels by low-severity hydrotreating of biocrude. In: Bridgwater, A.V., Boocock, D.G.B. (Eds.) Developments in Thermochemical Biomass Conversion, vol. 1. Blackie Academic \& Professional, London, pp. 611-621.
Junming, X., Jianchun, J., Yunjuan, S., Yanju, L., 2008. Bio-oil upgrading by means of ethyl ester production in reactive distillation to remove water and to improve storage and fuel characteristics. Biomass Bioenergy 32, 1056-1061.

Ismanto, A.E., Wang, S., Soetaredjo, F.E., Ismadji, S., 2010. Preparation of capacitor's electrode from cassava peel waste. Bioresour. Technol. 101, 3534-3540.

Kosasih, A.N., Febrianto, J., Sunarso, J., Ju, Y.H., Indraswati, N., Ismadji, S., 2010. Sequestering of $\mathrm{Cu}(\mathrm{II})$ from aqueous solution using cassava peel (Manihot esculenta). J. Hazard. Mater. 180, 366-374.

Kurniawan, A., Kosasih, A.N., Febrianto, J., Ju, Y.H., Sunarso, J., Indraswati, N., Ismadji, S., 2011. Evaluation of cassava peel waste as low cost biosorbent for Nisorption: equilibrium, kinetics, thermodynamics and mechanism. Chem. Eng. J. $172,158-166$.

Park, Y.K., Yoo, M.L., Heo, H.S., Lee, H.W., Park, S.H., Jung, S.C., Park, S.S., Seo, S.G., 2012. Wild reed of Suncheon Bay: potential bio-energy source. Renewable Energy 42, 168-172.

Pattiya, A., 2011. Bio-oil production via fast pyrolysis of biomass residues from cassava plants in a fluidised-bed reactor. Bioresour. Technol. 102, 1959-1967.

Pattiya, A., Sukkasi, S., Goodwin, V., 2012. Fast pyrolysis of sugarcane and cassava residues in a free-fall reactor. Energy 44, 1067-1077.

Van de Velden, M., Baeyens, J., Boukis, I., 2008. Modeling CFB biomass pyrolysis reactors. Biomass Bioenergy 31, 128-139.

Van de Velden, M., Baeyens, J., Brems, A., Jannsens, B., Dewil, R., 2010. Fundamentals, kinetics and endothermicity of the biomass pyrolysis reaction. Renewable Energy 35, 232-242.

Volli, V., Singh, R.K., 2012. Production of bio-oil from de-oiled cakes by thermal pyrolysis. Fuel 96, 579-585.

Weerachanchai, P., Tangsathitkulchai, C., Tangsathitkulchai, M., 2011. Characterization of products from slow pyrolysis of palm kernel cake and cassava pulp residue. Korean J. Chem. Eng. 28, 2262-2274. 